\title{
Immunological Protection against Digoxin Toxicity
}

\author{
Donald H. Schmidt and Vincent P. Butler, Jr. \\ From the Department of Medicine, Columbia University College of Physicians \\ and Surgeons, New York 10032
}

A в S T RACT. The lethal dose of digoxin was determined by administering $10 \mathrm{ml}$ of a digoxin-saline solution to 26 nonimmunized rabbits through an ear vein over a $10 \mathrm{~min}$ period. Rabbits receiving less than 0.45 $\mathrm{mg} / \mathrm{kg}$ digoxin showed no toxic effect, whereas all 15 rabbits that received $0.5 \mathrm{mg} / \mathrm{kg}$ developed an early arrhythmia and died within $1 \mathrm{hr}$. Moreover, eight rabbits which had been immunized with antigens unrelated to digoxin or injected with Freund's adjuvant mixture all died after receiving $0.6 \mathrm{mg} / \mathrm{kg}$ digoxin. Thus, it was concluded that $0.6 \mathrm{mg} / \mathrm{kg}$ digoxin was uniformly lethal in rabbits that had not been immunized or had received antigens unrelated to digoxin.

By way of contrast, 17 rabbits immunized with a digoxin-albumin conjugate in complete Freund's adjuvant formed digoxin-specific antibodies and survived doses of digoxin varying between 0.6 and $0.9 \mathrm{mg} / \mathrm{kg}$. In 10 rabbits immunized with digoxin-albumin conjugates, digoxin-specific antibody titers were determined following the administration of digoxin. There was a significant fall in antibody titer.

This study indicates that rabbits protected by digoxinspecific antibodies suffer no acute adverse effects from an amount of digoxin which is uniformly lethal in nonimmunized rabbits and in rabbits immunized with other antigens.

\section{INTRODUCTION}

The clinical use of cardiac glycosides is frequently accompanied by the development of toxic disturbances of cardiac rhythm and conduction (2), which may be life threatening. Since there is no specific antidote currently

This work was presented in part to the Annual Scientific Session of the American Heart Association, Miami Beach, Fla., 23 November 1968 (1).

Dr. Schmidt is a Clinical Science Fellow of the New York Heart Association. Dr. Butler is the recipient of a U. S. Public Health Service Research Career Development Award (1-K04-HE 11,315); this work was initiated while he was a Senior Investigator of the Arthritis Foundation.

Received for publication 10 June 1970 and in revised form 23 October 1970.

available, the present study was designed to determine whether antibodies specific for digoxin would confer protection against the toxic effects of this cardiac glycoside. Butler and Chen have previously demonstrated that rabbits immunized with synthetic digoxin-protein conjugates produce antibodies specific for digoxin, (3) and, more recently, Watson and Butler performed in vitro studies which showed that these antibodies are capable of preventing the effect of digoxin on cellular potassium transport (4). This report presents evidence that antidigoxin antibodies are also effective in vivo and that these antibodies protect rabbits from the toxic effects of an otherwise lethal amount of digoxin.

\section{METHODS}

Preparation of antigens. Digoxin ${ }^{1}$ was chemically coupled as a hapten to bovine serum albumin $(B S A)^{2}$ or to human albumin (HSA) ${ }^{2}$ by the periodate oxidation method $(3,5)$, as described in detail elsewhere (6).

Immunization. White New Zealand rabbits, weighing 2-3 $\mathrm{kg}$, were immunized by the injection of BSA-digoxin (BSADig) or with HSA-digoxin (HSA-Dig), $1 \mathrm{mg} / \mathrm{ml}$, in complete Freund's adjuvant mixture. After an initial series of three weekly $0.4-\mathrm{ml}$ injections $(0.1 \mathrm{ml}$ into each of four individual toe pads), subsequent $0.4-\mathrm{ml}$ booster injections were given at 2- to 4-wk intervals until the animals were studied. Control rabbits were immunized in a similar manner with BSA, purin-6-oyl-bovine serum albumin (PurBSA) conjugates (7) or with $0.85 \%$ saline solution alone in complete Freund's adjuvant mixture. The duration of immunization and the number of antigen injections are listed in Tables I and II. Serum was obtained by cardiac puncture or from an ear vein on the day before the intravenous injection of digoxin. In a group of 10 rabbits with digoxinspecific antibodies, serum was obtained 1 day and again 1 wk after the intravenous administration of digoxin.

Determination of antibody concentration. The presence of digoxin-specific antibodies was determined by the dextran-coated charcoal method of Herbert, Lau, Gottlieb, and Bleicher (8) as modified by Smith, Butler, and Haber (9). The test was carried out as follows: to $2 \mathrm{ml}$ of various dilutions of test serum in Tris-buffered $0.35 \%$ HSA $(7 \mathrm{ml}$

\footnotetext{
${ }^{1}$ Courtesy of Dr. Stanley L. Bloomfield, Burroughs Welcome \& Co. (U.S.A.) Inc., Tuckahoe, N. Y.

${ }^{2}$ Fraction V powder; Pentex Biochemical, Kankakee, Ill.
} 
5\% $\mathrm{HSA}^{\mathrm{s}}$ plus $93 \mathrm{ml}$ Tris-buffered saline, $\mathrm{pH} 7.4$ [10]) was added $64 \mathrm{~m} \mu \mathrm{g}$ digoxin- ${ }^{-3} \mathrm{H}$ (randomly labeled; $126 \mu \mathrm{c}$ / $\mathrm{mg}^{1}$ ) in $2 \mathrm{ml}$ of the same buffer. The reagents were mixed and incubated at $37^{\circ} \mathrm{C}$ for $2 \mathrm{hr} .2 \mathrm{ml}$ of dextran T $70^{4}$-coated charcoal, prepared as described by Herbert et al. (8), was then added. The contents of the test tubes were mixed and then centrifuged at $2000 \mathrm{rpm}$ for $30 \mathrm{~min}$ at $4^{\circ} \mathrm{C}$. $1 \mathrm{ml}$ aliquots of the supernatant were mixed with $15 \mathrm{ml}$ of liquid scintillation counting solution similar to that used by Turner (11), (4.50 g 2,5-diphenyloxazole, $100 \mathrm{mg}$ 1,4-bis-2-[4methyl-5 phenyloxazolyl]-benzene, ${ }^{\circ} 333 \mathrm{ml}$ Triton X-100, $667 \mathrm{ml}$ toluene). After cooling to $4^{\circ} \mathrm{C}$ followed by vigorous shaking, radioactivity was determined by counting in a TriCarb liquid scintillation counter. ${ }^{\circ}$ Correction for quenching was initially made using an automatic external standard and later by recounting each sample after addition of an internal standard of digoxin- ${ }^{3} \mathrm{H}$. The binding of digoxin- ${ }^{3} \mathrm{H}$ was expressed as the percentage of added radioactivity present in the supernatant after correction for the small amount (about $1 \%$ ) of radioactivity present in coated charcoal supernatant solutions when digoxin- ${ }^{3} \mathrm{H}$ was mixed with buffered HSA in the absence of test serum. The binding of digoxin $-{ }^{8} \mathrm{H}$ was determined at dilutions of antiserum capable of binding more than and less than $50 \%$ of the added digoxin. Titers, which are functions of both antibody affinity and concentration, are expressed as the dilutions of antiserum (calculated by extrapolation and rounded off to the nearest unit divisible by 50 ) capable of binding $50 \%$ of the added digoxin $-{ }^{8} \mathrm{H}$.

The presence of antibodies to the various protein antigens used in this study was determined by the bis-diazotized benzidine hemagglutination method (12). Sera which had previously been heated to $56^{\circ} \mathrm{C}$ for $30 \mathrm{~min}$ and absorbed three times with washed human group " $A$ " erythrocytes were serially diluted in a diluent consisting of normal rabbit serum (also heated and absorbed as described above) diluted 1:100 in $0.15 \mathrm{M}$ phosphate-buffered saline solution, $\mathrm{pH}$ 7.3. To $0.5 \mathrm{ml}$ of each serum dilution was added $0.05 \mathrm{ml}$ of human group " $A$ " erythrocytes which had been coated with BSADig, HSA-Dig, Pur-BSA, or with BSA using bis-diazotized benzidine, as previously described. Hemagglutination results were determined by settling patterns after $16 \mathrm{hr}$ incubation at room temperature, as previously described; titers were recorded as the highest dilutions of sera which yielded an agglutination pattern of two-plus or greater (12).

Administration of digoxin. Unanesthetized rabbits whose weights ranged between 2.6 and $4.8 \mathrm{~kg}$ were given $10 \mathrm{ml}$ of a digoxin solution (digoxin $0.25 \mathrm{mg} / \mathrm{ml}$ in a $40 \%$ propylene glycol-10\% ethanol solution ${ }^{1}$ made up to $10 \mathrm{ml}$ with isotonic $\mathrm{NaCl}$ ) through an ear vein over a $10 \mathrm{~min}$ period while held in a metal bleeding cage. ${ }^{7}$ Using an oscilloscopic recorder $^{8}$ and needle electrodes, the electrocardiogram was monitored continuously for a $30 \mathrm{~min}$ control period before the administration of digoxin, during the infusion of digoxin, and for $2 \mathrm{hr}$ thereafter. The electrocardiogram was recorded at rapid paper speeds $(75 \mathrm{~mm} / \mathrm{sec})$ every $10 \mathrm{~min}$ and analyzed for heart rate, rhythm, and $\mathrm{P}-\mathrm{R}$ interval.

Two rabbits given $10 \mathrm{ml}$ of the diluent $(40 \%$ propylene glycol-10\% ethanol) over a $10 \mathrm{~min}$ period showed no change in heart rate or rhythm during $2 \mathrm{hr}$ of constant electrocardiographic monitoring.

${ }^{3}$ Albumisol; Merck Sharp and Dohme, West Point, Pa.

- Pharmacia Fine Chemicals Inc., Piscataway, N. J.

${ }^{5}$ Norit-A ; Fisher Scientific Company, Pittsburgh, Pa.

- Packard Instrument Co., Inc., Downers Grove, Ill.

${ }^{7}$ Porter Mathews Scientific Co., Princeton, N. J.

${ }^{8}$ Electronics for Medicine, Inc., White Plains, N. Y.

\section{RESULTS}

Digoxin toxicity in nonimmunized rabbits. 26 normal control rabbits were given varying amounts of digoxin to determine the lethal dose. Nine rabbits that received less than $0.45 \mathrm{mg}$ digoxin per $\mathrm{kg}$ body weight showed no toxic effects. Of two rabbits that were given $0.45 \mathrm{mg} / \mathrm{kg}$, one lived and one died. All 15 rabbits receiving $0.5 \mathrm{mg}$ digoxin per $\mathrm{kg}$ developed an arrhythmia within $25 \mathrm{~min}$ and died within 1-2 $\mathrm{hr}$.

The effect of digoxin on heart rate in these nonimmunized rabbits is illustrated in Fig. 1. Except for an initial slight slowing in heart rate, little effect was observed in rabbits receiving less than $0.45 \mathrm{mg} / \mathrm{kg}$, a nonlethal amount. A lethal dose, $0.5 \mathrm{mg} / \mathrm{kg}$, caused an early arrhythmia and, in general, a marked fall in heart rate leading to death within $120 \mathrm{~min}$. Specifically, this decrease in heart rate was first produced by sinus slowing, then by various forms of atrioventricular block progressing to complete heart block. Ventricular arrhythmias were common as manifested by ventricular ectopic contractions, brief periods of ventricular tachycardia, and occasional ventricular fibrillation. A slow idioventricular rhythm, often with no evidence of atrial activity, was the usual terminal rhythm and was accompanied by a respiratory arrest. Atrial or supraventricular dysrhythmias were rare, but in some instances the terminal events were preceded by a supraventricular tachycardia (Fig. 1).

Digoxin toxicity in rabbits immunized with antigens unrelated to digoxin. To determine if immunization with unrelated antigens or the use of complete Freund's adjuvant mixture alone might confer nonspecific protection, a second group of 21 rabbits was studied. As shown in Table $I$, nine rabbits had been immunized with Pur-BSA and seven with BSA; an additional five rabbits were injected with only complete Freund's adjuvant and saline (Adj). The duration of immunization, the number of injections, and the antibody titers are listed in Table I. The sera of animals immunized with Pur-BSA and with BSA, respectively, contained significant amounts of hemagglutinating antibodies to the corresponding antigens, but did not possess any significant digoxin-binding capacity (Table I).

All five rabbits (Table I) that received the dose which proved lethal in nonimmunized rabbits, $0.5 \mathrm{mg}$ digoxin per $\mathrm{kg}$, lived. Of the eight rabbits that were given 0.55 $\mathrm{mg}$ digoxin per $\mathrm{kg}$, six died and two lived. All eight rabbits receiving $0.6 \mathrm{mg} / \mathrm{kg}$, developed an early arrhythmia and died within $2 \mathrm{hr}$. Of particular interest is the fact that two of the survivors, rabbit FE-1, which received $0.5 \mathrm{mg}$ digoxin per $\mathrm{kg}$, and rabbit $\mathrm{FE}-2$, given $0.55 \mathrm{mg} / \mathrm{kg}$, had been injected only with saline in complete Freund's adjuvant mixture.

Effect of a toxic amount of digoxin in rabbits immunized with digoxin protein conjugates. 17 rabbits were 

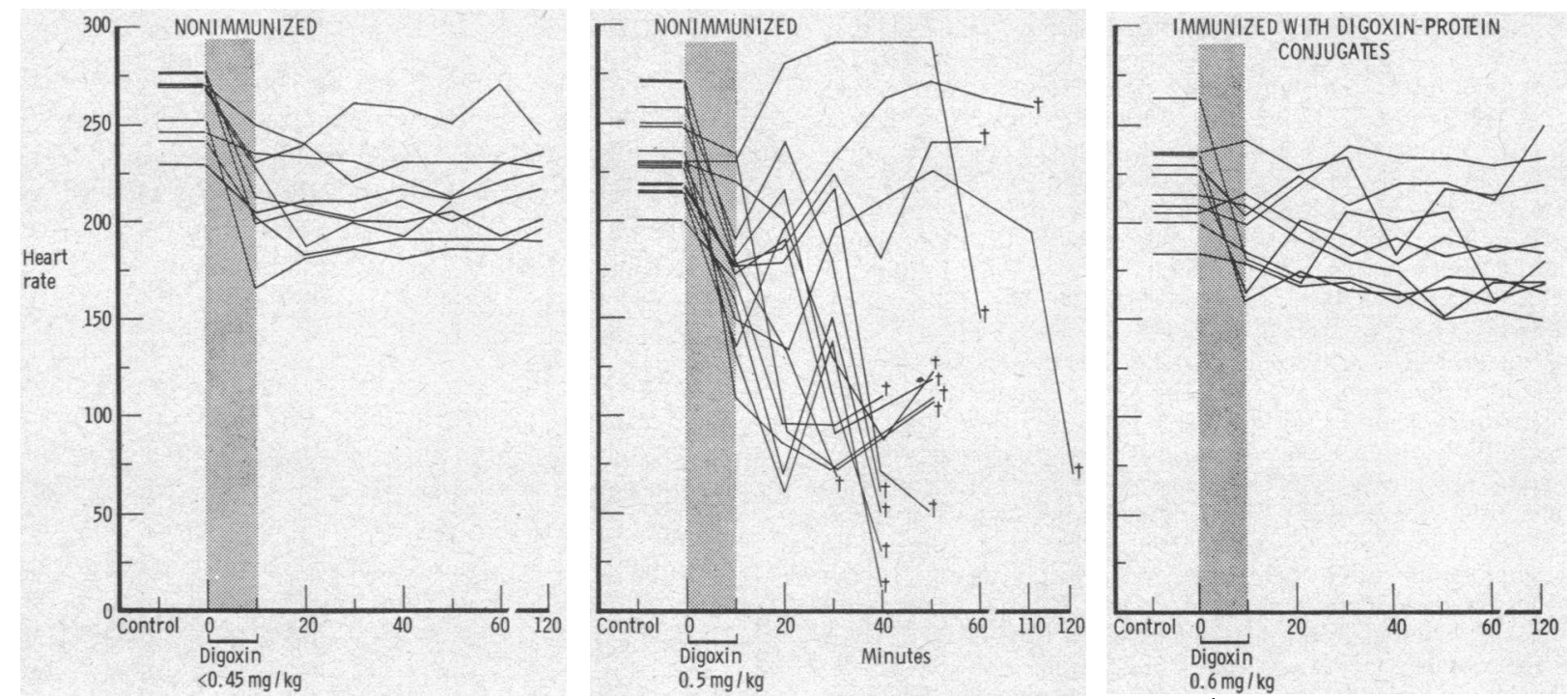

FIGURE 1 The effect of different doses of digoxin on the heart rate of three groups of rabbits: 9 nonimmunized rabbits given $0.2-0.45 \mathrm{mg}$ digoxin per $\mathrm{kg}$ (a nonlethal amount), 15 nonimmunized rabbits given $0.5 \mathrm{mg} / \mathrm{kg}$ (a lethal amount), and 10 rabbits immunized with digoxin-protein conjugates which received $0.6 \mathrm{mg} / \mathrm{kg}$. The straight line during the $30 \mathrm{~min}$ control period before the administration of digoxin represents the average of three or more recordings of heart rate in each animal; subsequent determinations of rate are recorded at 10-min intervals during the infusion of digoxin (represented by the shaded area) and for $2 \mathrm{hr}$ thereafter. A cross indicates the time of death.

immunized with digoxin-protein conjugates. The type of immunizing antigen, the duration of immunization, the number of antigen injections, and the antibody titers are listed in Table II. These animals formed significant quantities of hemagglutinating antibodies to the corresponding antigen. Moreover, their sera contained digoxinbinding antibodies in significant amounts (Table II).

10 rabbits were given $0.6 \mathrm{mg}$ digoxin per $\mathrm{kg}$ (an amount lethal in nonimmunized rabbits and in rabbits immunized with antigens unrelated to digoxin) and lived (Table II). In contrast with nonimmunized rabbits receiving $0.5 \mathrm{mg}$ digoxin per $\mathrm{kg}$, these 10 animals showed no significant change in heart rate or rhythm (Fig. 1). Five of the rabbits were given still larger doses of digoxin, varying from 0.65 to $0.9 \mathrm{mg}$ digoxin per $\mathrm{kg}$ body weight, and survived; doses of $1.0 \mathrm{mg} / \mathrm{kg}$ and $1.2 \mathrm{mg} / \mathrm{kg}$, respectively, were lethal in two rabbits immunized with digoxin-protein conjugates (Table II).

Antibody titers after the administration of digoxin. In 10 rabbits immunized with digoxin-protein conjugates, digoxin-binding capacities were determined in sera obtained the day before, the day after, and 7 days after the intravenous administration of $0.6 \mathrm{mg}$ digoxin per $\mathrm{kg}$ (Table III). Sera from all animals except rabbit DC-17 showed a decrease in digoxin-binding capacity 1 day after the digoxin infusion; the decrease in binding capacity was statistically significant $(P<0.005)$ in this group of rabbits (13). Digoxin-binding capacity re- mained low in all sera (except from rabbit DC-17) 1 wk later; there was no significant difference between binding capacity 1 day after and 1 wk after digoxin administration. The binding capacity $1 \mathrm{wk}$ after study was again significantly less, however, than on the day before the study $(P<0.005)$.

\section{DISCUSSION}

This study presents evidence that the intravenous administration of $0.5 \mathrm{mg}$ digoxin per $\mathrm{kg}$ over a $10 \mathrm{~min}$ period is uniformly lethal in nonimmunized rabbits (Fig. 1). Four rabbits immunized with antigens unrelated to digoxin and one rabbit injected with saline alone in complete Freund's adjuvant mixture suffered no adverse electrocardiographic effects after receiving this dose of digoxin (Table I). The basis for the increased resistance to digoxin in these animals is not clear. They were maintained under laboratory conditions identical with those of the nonimmunized rabbits. They were somewhat smaller (mean weight: $3.08 \pm 0.38 \mathrm{~kg}$ ) than the nonimmunized animals (mean weight: $3.76 \pm 0.5$ $\mathrm{kg}$ ) so immaturity could conceivably have been a factor in their resistance to digoxin. Another possible basis for their increased resistance to this glycoside is that of a nonspecific reticuloendothelial response to immunization. There is, however, no evidence at present to support either of these explanations. 
Although five rabbits immunized with antigens unrelated to digoxin or with saline alone in complete Freund's adjuvant mixture tolerated $0.5 \mathrm{mg}$ digoxin per $\mathrm{kg}$, six of eight such animals died after receiving 0.55 $\mathrm{mg} / \mathrm{kg}$, and all eight rabbits from this control group, receiving $0.6 \mathrm{mg} / \mathrm{kg}$, died (Table I). In contrast with the control animals, 15 rabbits whose sera contained antibodies to digoxin received intravenous doses of from 0.6 to $0.9 \mathrm{mg} / \mathrm{kg}$ of this glycoside and lived. Since 9 of these 15 animals (DC-10 through DC-18) had been immunized for relatively long periods (34-62 wk) and had received from 8 to 18 injections of antigen (Table II), the possibility was considered that the protective effect observed in these animals might reflect a nonspecific protective effect, perhaps related to duration or intensity of immunization, similar to the nonspecific protective effect in the control rabbits immunized with antigens unrelated to digoxin. However, six of the animals whose sera contained antibodies to digoxin (those in the DB series) had been immunized for much briefer periods
(7-10 wk) and had only received three or four antigen injections (Table II). In contrast, longer periods of immunization (8-20 wk) with somewhat more antigenic stimulation (five or six injections in most animals) failed to confer any significant protective effect on rabbits immunized with control antigens, receiving 0.55 or $0.6 \mathrm{mg}$ digoxin per $\mathrm{kg}$ (Table I). It was therefore concluded that rabbits whose sera contain antibodies to digoxin are specifically protected from the toxic effects of $0.6 \mathrm{mg}$ digoxin per $\mathrm{kg}$, a dose which was uniformly lethal in nonimmunized rabbits and in rabbits immunized with antigens unrelated to digoxin. Antibodies specific for other low molecular weight substances of physiological importance have similarly been shown to have biological activity (14-20).

The mechanism by which the protective effect of digoxin-specific antibodies is exerted has not been established in the current study. The protective effect of antibody may reflect $(a)$ prevention of digoxin uptake by the myocardium as a result of binding of the glyco-

TABLE I

Summary of Immunization Data, Antibody Titers, and Results of Digoxin Infusion in Rabbits Immunized with Antigens Unrelated to Digoxin

\begin{tabular}{|c|c|c|c|c|c|c|c|c|}
\hline $\begin{array}{c}\text { Rabbit } \\
\text { no. }\end{array}$ & $\begin{array}{c}\text { Immunizing } \\
\text { antigen }\end{array}$ & $\begin{array}{c}\text { Wk of } \\
\text { immuni- } \\
\text { zation }\end{array}$ & $\begin{array}{c}\text { No. of } \\
\text { antigen } \\
\text { injections }\end{array}$ & $\begin{array}{l}\text { Hemagglutinating } \\
\text { antibody } \\
\text { titer* }\end{array}$ & $\begin{array}{l}\text { Digoxin- } \\
\text { binding } \\
\text { antibody } \\
\text { titer } \neq\end{array}$ & Weight & $\begin{array}{l}\text { Amount of } \\
\text { digoxin } \\
\text { given }\end{array}$ & Result \\
\hline & & & & & & $\mathrm{kg}$ & $\mathrm{mg} / \mathrm{kg}$ & \\
\hline BSA-5 & BSA & 5 & 3 & ND & $0 \S$ & 2.9 & 0.5 & Lived \\
\hline BSA-6 & BSA & 6 & 3 & ND & $0 \S$ & 3.3 & 0.5 & Lived \\
\hline TCP-24 & Pur-BSA & 3 & 3 & ND & $0 \S$ & 3.0 & 0.5 & Lived \\
\hline TCP-25 & Pur-BSA & 4 & 3 & ND & $0 \S$ & 2.6 & 0.5 & Lived \\
\hline FE-1 & Adj & 14 & 4 & & 0 & 3.6 & 0.5 & Lived \\
\hline BSA-9 & BSA & 18 & 5 & $>1: 51,200$ & 0 & 4.3 & 0.55 & Died \\
\hline BSA-10 & BSA & 14 & 4 & ND & ND & 3.4 & 0.55 & Died \\
\hline BSA-12 & BSA & 17 & 5 & $>1: 51,200$ & 0 & 4.0 & 0.55 & Died \\
\hline TCP-26 & Pur-BSA & 7 & 3 & ND & $0 \S$ & 2.8 & 0.55 & Died \\
\hline TCP-28 & Pur-BSA & 19 & 6 & $1: 12,800$ & 0 & 3.3 & 0.55 & Lived \\
\hline TCP-31 & Pur-BSA & 15 & 5 & ND & ND & 3.4 & 0.55 & Died \\
\hline TCP-32 & Pur-BSA & 19 & 5 & $1: 12,800$ & 0 & 3.6 & 0.55 & Died \\
\hline FE-2 & Adj & 16 & 5 & & 0 & 3.8 & 0.55 & Lived \\
\hline BSA-8 & BSA & 20 & 5 & $>1: 51,200$ & 0 & 4.0 & 0.6 & Died \\
\hline BSA-11 & BSA & 20 & 5 & $1: 25,600$ & 0 & 3.1 & 0.6 & Died \\
\hline TCP-27 & Pur-BSA & 8 & 3 & ND & $0 \S$ & 4.2 & 0.6 & Died \\
\hline TCP-29 & Pur-BSA & 20 & 6 & $1: 12,800$ & 0 & 3.4 & 0.6 . & Died \\
\hline TCP-30 & Pur-BSA & 19 & 6 & $1: 12,800$ & 0 & 3.4 & 0.6 & Died \\
\hline FE-3 & Adj & 16 & 5 & & 0 & 2.9 & 0.6 & Died \\
\hline FE-4 & Adj & 17 & 5 & & 0 & 3.6 & 0.6 & Died \\
\hline FE-5 & Adj & 17 & 5 & & 0 & 4.0 & 0.6 & Died \\
\hline
\end{tabular}

Adj $=0.85 \% \mathrm{NaCl}$ in complete Freund's adjuvant mixture $\mathrm{ND}=$ Not done.

* Hemagglutination titer determined in each instance with cells coated with immunizing antigen; see Methods section for definition of hemagglutinating antibody titer.

$\ddagger$ See Methods section for definition of digoxin-binding antibody titer.

$\S$ No binding as determined by equilibrium dialysis (3). 
TABLE II

Summary of Immunization Data, Antibody Titers, and Results of Digoxin Infusion in Rabbits Immunized with Digoxin-Albumin Conjugates

\begin{tabular}{|c|c|c|c|c|c|c|c|c|}
\hline $\begin{array}{c}\text { Rabbit } \\
\text { no. }\end{array}$ & $\begin{array}{l}\text { Immunizing } \\
\text { antigen }\end{array}$ & $\begin{array}{l}\text { Wk of } \\
\text { immuni- } \\
\text { zation }\end{array}$ & $\begin{array}{c}\text { No. of } \\
\text { antigen } \\
\text { injections }\end{array}$ & $\begin{array}{c}\text { Hemagglutinating } \\
\text { antibody } \\
\text { titer* }\end{array}$ & $\begin{array}{c}\text { Digoxin- } \\
\text { binding } \\
\text { antibody } \\
\text { titer } \ddagger\end{array}$ & Weight & $\begin{array}{l}\text { Amount of } \\
\text { digoxin } \\
\text { given }\end{array}$ & Result \\
\hline & & & & & & $\mathrm{kg}$ & $m g / k g$ & \\
\hline DC-10 & HSA-Dig & 62 & 18 & $1: 100$ & $1: 550$ & 3.9 & 0.6 & Lived \\
\hline DC-11 & HSA-Dig & 57 & 17 & $1: 800$ & $1: 1400$ & 3.8 & 0.6 & Lived \\
\hline DC-12 & HSA-Dig & 60 & 18 & $1: 400$ & $1: 600$ & 3.9 & 0.6 & Lived \\
\hline DC-17 & HSA-Dig & 34 & 8 & $1: 1600$ & $1: 50$ & 4.0 & 0.6 & Lived \\
\hline DB-68 & BSA-Dig & 7 & 3 & $1: 6400$ & $1: 200$ & 3.6 & 0.6 & Lived \\
\hline DB-69 & BSA-Dig & 8 & 3 & ND & $1: 300$ & 3.4 & 0.6 & Lived \\
\hline DB-70 & BSA-Dig & 8 & 3 & $1: 6400$ & $1: 1000$ & 3.5 & 0.6 & Lived \\
\hline DB-71 & BSA-Dig & 9 & 3 & ND & $1: 1200$ & 3.0 & 0.6 & Lived \\
\hline DB-73 & BSA-Dig & 10 & 4 & ND & $1: 950$ & 3.6 & 0.6 & Lived \\
\hline DB-75 & BSA-Dig & 10 & 4 & ND & $1: 1600$ & 3.8 & 0.6 & Lived \\
\hline DC-18 & HSA-Dig & 48 & 11 & $1: 400$ & $1: 400$ & 4.0 & 0.65 & Lived \\
\hline DC-13 & HSA-Dig & 48 & 11 & $1: 400$ & $1: 400$ & 4.0 & 0.7 & Lived \\
\hline DC-15 & HSA-Dig & 49 & 11 & $1: 400$ & $1: 550$ & 4.5 & 0.75 & Lived \\
\hline DC-14 & HSA-Dig & 49 & 11 & $1: 200$ & $1: 700$ & 3.5 & 0.8 & Lived \\
\hline DC-16 & HSA-Dig & 49 & 11 & $1: 1800$ & $1: 600$ & 3.9 & 0.9 & Lived \\
\hline DC-19 & HSA-Dig & 10 & 6 & $1: 1600$ & $1: 400$ & 4.4 & 1.0 & Died \\
\hline DC-20 & HSA-Dig & 10 & 6 & $1: 3200$ & $1: 200$ & 4.3 & 1.2 & Died \\
\hline
\end{tabular}

$\mathrm{ND}=$ Not done.

* Hemagglutination titer determined in each instance with conjugate used for immunization; see Methods section for definition of hemagglutinating antibody titer.

$\ddagger$ See Methods section for definition of digoxin-binding antibody titer.

side by antibody in plasma and other extracellular fluids, or $(b)$ the uptake of digoxin by the myocardium in the form of a pharmacologically inert complex with its specific antibody. We favor the former mechanism on the basis of in vitro studies in which antibody was shown to prevent the uptake of digoxin- ${ }^{3} \mathrm{H}$ by rat renal cortical cells and by human erythrocytes (4).

Whatever the mechanism may be, the results clearly indicate that antibodies to digoxin, like antibodies to diphtheria and tetanus toxins, are effective in conferring specific protection against the toxic effects of the corresponding antigen. Antibodies to bacterial toxins have not been shown to be effective in the reversal of established toxic cellular effects. Antibodies to digoxin have, however, been found to be effective in removing this glycoside from rat renal cortical cells and from human erythrocytes in vitro; in removing digoxin from the latter cells, antibodies have been found to be capable of reversing a pharmacologic effect of the glycoside, namely, its capacity to inhibit potassium uptake by these erythrocytes (4). These latter in vitro observations coupled with the in vivo findings of the current report suggested that antidigoxin antibodies might be capable of reversing established digoxin toxicity in experimental animals and, eventually, perhaps in humans with severe, life-threatening digoxin toxicity. Recently, it has been demonstrated that antidigoxin antibodies can reverse established digoxin toxicity in the nonimmunized dog; this study will be the subject of a separate report (21).

Following the intravenous administration of a large dose of digoxin to immunized rabbits, the digoxin-binding capacity of their sera was significantly decreased (Table III). The persistence of digoxin in the circulation in complex with antibody would account for a decreased capacity to bind digoxin- ${ }^{3} \mathrm{H}$ in vitro; in support of this hypothesis are the observations that low molecular weight antigens such as insulin (22) and folic acid (23) persist in the circulation for longer periods when administered in the presence of antibody. An alternative explanation is that this decreased digoxin-binding capacity reflects clearance of antibody-digoxin complexes from the circulation in a manner analagous to that described by Dixon, Vazquez, Weigle, and Cochrane for antibody-antigen complexes involving high molecular weight antigens (24). It is also possible that the persistence of a diminished digoxin-binding capacity $1 \mathrm{wk}$ later may reflect an element of diminished antibody production due to the presence of excess antigen (digoxin) (25). 
TABLE III

Per Cent Digoxin $-^{3} \mathrm{H}$ Bound by Sera Obtained before and after Digoxin Administration* from Rabbits with Antidigoxin Antibodies

\begin{tabular}{ccccc}
\hline & & \multicolumn{3}{c}{ Per cent digoxin-3H bound $\ddagger$} \\
\cline { 4 - 5 } $\begin{array}{c}\text { Rabbit } \\
\text { no. }\end{array}$ & $\begin{array}{c}\text { Serum } \\
\text { dilution } \\
\text { tested }\end{array}$ & $\begin{array}{c}\text { Day } \\
\text { before }\end{array}$ & $\begin{array}{c}\text { Day } \\
\text { after }\end{array}$ & $\begin{array}{c}\text { Wk } \\
\text { after }\end{array}$ \\
\hline DC-10 & $1: 400$ & 61 & 26 & 27 \\
DC-11 & $1: 1600$ & 42 & 27 & 32 \\
DC-12 & $1: 800$ & 39 & 22 & 19 \\
DC-13 & $1: 400$ & 48 & 19 & 26 \\
DC-14 & $1: 400$ & 68 & 30 & 35 \\
DC-15 & $1: 400$ & 63 & 28 & 22 \\
DC-16 & $1: 800$ & 39 & 25 & 26 \\
DC-17 & $1: 50$ & 52 & 73 & 81 \\
DC-18 & $1: 200$ & 77 & 39 & 40 \\
DB-70 & $1: 800$ & 36 & 22 & 24
\end{tabular}

* All rabbits received $0.6 \mathrm{mg}$ digoxin per $\mathrm{kg}$ except $\mathrm{DC}-18$ which received $0.65 \mathrm{mg} / \mathrm{kg}$.

$\ddagger$ Results are expressed as per cent of $64 \mathrm{~m} \mu \mathrm{g}$ digoxin- ${ }^{3} \mathrm{H}$ bound by $2 \mathrm{ml}$ of the serum dilution used; see Methods section for details.

\section{ACKNOWLEDGMENTS}

We are indebted to Bette M. Kaufman, Patricia L. Fleming, and Toni $\mathrm{H}$. Greene for excellent technical assistance.

This investigation was supported by research grants from the U. S. Public Health Service (HE-10608, AM-07183, HE-02001, HE-05741), the New York Heart Association, the New York Chapter of the Arthritis Foundation, and the Lupus Erythematosus Foundation.

\section{REFERENCES}

1. Schmidt, D. H., and V. P. Butler, Jr. 1968. Immunological protection against digitalis toxicity. Circulation. 38 (Suppl. 6) : 174. (Abstr.)

2. Irons, G. V., Jr., and E. S. Orgain. 1966. Digitalisinduced arrhythmias and their management. Progr. Cardiovasc. Dis. 8: 539.

3. Butler, V. P., Jr., and J. P. Chen. 1967. Digoxin-specific antibodies. Proc. Nat. Acad. Sci. U.S.A. 57: 71.

4. Watson, J. F., and V. P. Butler, Jr. 1968. Biologic activity of digoxin-specific antisera. Clin. Res. 16: 252. (Abstr.).

5. Erlanger, B. F., and S. M. Beiser. 1964. Antibodies specific for ribonucleosides and ribonucleotides and their reaction with DNA. Proc. Nat. Acad. Sci. U.S.A. 52: 68.

6. Smith, T. W., V. P. Butler, Jr., and E. Haber. 1970. Characterization of antibodies of high affinity and specificity for the digitalis glycoside digoxin. Biochemistry. 9: 331 .

7. Butler, V. P., Jr., S. M. Beiser, B. F. Erlanger, S. W. Tanenbaum, S. Cohen, and A. Bendich. 1962. Purine- specific antibodies which react with deoxyribonucleic acid (DNA). Proc. Nat. Acad. Sci. U.S.A. 48: 1597.

8. Herbert, V., K. S. Lau, C. W. Gottlieb, and S. J. Bleicher. 1965. Coated charcoal immunoassay of insulin. J. Clin. Endocrinol. Metab. 25: 1375.

9. Smith, T. W., V. P. Butler, Jr., and E. Haber. 1969. Determination of therapeutic and toxic serum digoxin concentrations by radioimmunoassay. N. Engl. J. Med. 281: 1212 .

10. Butler, V. P., Jr., S. W. Tanenbaum, and S. M. Beiser. 1965. A study of the cross-reactivity of antipurin-6-oyl serum with deoxyribonucleic acid (DNA). J. Exp. Med. $121: 19$.

11. Turner, J. C. 1969. Tritium counting with the Triton X-100 scintillant. Int. J. Appl. Radiat. Isotop. 20: 499.

12. Butler, V. P., Jr., and J. H. Vaughan. 1964. Hemagglutination by rheumatoid factor of cells coated with animal gamma globulins. Proc. Soc. Exp. Biol. Med. 116: 585.

13. Snedecor, G. W., and W. G. Cochran. 1967. Statistical Methods. The Iowa State University Press, Ames. 6th edition.

14. Goodfriend, L., and A. H. Sehon. 1961. Antibodies to estrone-protein conjugates. II. Endocrinological studies. Can. J. Biochem. 39: 961.

15. Neri, R. O., S. Tolksdorf, S. M. Beiser, B. F. Erlanger, F. J. Agate, Jr., and S. Lieberman. 1964. Further studies on the biological effects of passive immunization with antibodies to steroid-protein conjugates. Endocrinology. 74: 593.

16. Ranadive, N. S., and A. H. Sehon. 1967. Antibodies to serotonin. Can. J. Biochem. 45: 1701.

17. Oken, D. E., and T. U. L. Biber. 1968. Biologically effective immunization against angiotension. Amer. J. Physiol. 214: 791.

18. Ungar-Waron, H., and M. Sela. 1966. Pyridoxal-specific antibodies obtained with a synthetic pyridoxalpolypeptide conjugate. Biochim. Biophys. Acta. 124: 147.

19. Davis, T. R. A., and T. L. Goodfriend. 1969. Neutralization of airway effects of bradykinin. Amer. J. Physiol. $217: 73$.

20. Davis, T. R. A., and K. M. Meade. 1970. Biologically active antibodies to histamine. Nature (London). 226: 360.

21. Schmidt, D. H., and V. P. Butler, Jr., 1969. Reversal of digoxin toxicity with specific antibodies. J. Clin. Invest. 48: 74a. (Abstr.)

22. Berson, S. A., R. S. Yalow, A. Bauman, M. A. Rothschild, and K. Newerly. 1956. Insulin- $\mathrm{I}^{131}$ metabolism in human subjects: demonstration of insulin binding globulin in the circulation of insulin treated subjects. J. Clin. Invest. 35: 170 .

23. Rothenberg, S. P., F. Gizis, and B. Kamen. 1969. Antibodies against folic acid. I. In vitro biophysical effect. J. Lab. Clin. Med. 74: 662 .

24. Dixon, F. J., J. J. Vazquez, W. O. Weigle, and C. G. Cochrane. 1959. Immunology and pathogenesis of experimental serum sickness. In Cellular and Humoral Aspects of the Hypersensitive States. H. S. Lawrence, editor. Paul B. Hoeber, Inc., New York. 345.

25. Francis, T. C., and W. E. Paul. 1970. Inhibition by hapten of cellular immune responses to a hapten-protein conjugate. Nature (London). 226: 173. 